\title{
REVIEW
}

\section{Toxicodendron Dermatitis: Poison Ivy, Oak, and Sumac}

\author{
Aaron C. Gladman, MD
}

From the Department of Emergency Medicine, Harbor-UCLA Medical Center, Torrance, CA.

\begin{abstract}
Allergic contact dermatitis caused by the Toxicodendron (formerly Rhus) species - poison ivy, poison oak, and poison sumac - affects millions of North Americans every year. In certain outdoor occupations, for example, agriculture and forestry, as well as among many outdoor enthusiasts, Toxicodendron dermatitis presents a significant hazard. This review considers the epidemiology, identification, immunochemistry, pathophysiology, clinical features, treatment, and prevention of this common dermatologic problem. Recent research in prevention is emphasized, and resources to help in the identification of plants are provided in the bibliography. The literature was searched using a MEDLINE query for "Toxicodendron dermatitis," and the identified article bibliographies were searched as well.
\end{abstract}

Key words: Toxicodendron dermatitis, rhus dermatitis, poison ivy, poison oak, poison sumac, urushiol

\section{Introduction}

The weeping, itchy rash caused by poison ivy, poison oak, and poison sumac is the single most common allergic contact dermatitis in North America, affecting 1050 million Americans per year. ${ }^{1}$ It is a disorder wellknown to most emergency and primary care physicians, dermatologists, and the lay public. It is a significant occupational hazard in agriculture and forestry, and afflicts many unwary recreational wilderness users. Disability and treatment result in substantial medical costs every year. This review discusses the epidemiology and pathophysiology of Toxicodendron dermatitis, and current treatment and prevention.

\section{Epidemiology}

Contact dermatitis and other eczemas are diagnosed at more than 7.1 million office visits and 430000 hospital outpatient visits in the United States every year. ${ }^{2}$ Members of the family Anacardiaceae cause more allergic contact dermatitis than all other plants combined. In the United States, the genus causing the most significant medical morbidity is Toxicodendron (formerly Rhus), which includes $T$ radicans (poison ivy), $T$ diversilobum (poison oak), and $T$ vernix (poison sumac or dogwood). Wilderness, rural, and even suburban outdoor activities,

Corresponding author: Aaron C. Gladman, MD, Department of Emergency Medicine, Harbor-UCLA Medical Center, 1000 West Carson Street, Torrance, CA 90504 (e-mail: agladman@ dhs.co.la.ca.us). as well as outdoor occupations related to agriculture, forestry, and firefighting, are at high risk and incur significant monetary expense for worker disability and medical treatment. For example, Toxicodendron dermatitis causes $10 \%$ of total US Forest Services lost-time injuries, ${ }^{3}$ and approximately one third of forestry workers in California, Oregon, and Washington are disabled by poison oak dermatitis each fire season. ${ }^{4}$ The cost of treatment for this disease has accounted for up to $1 \%$ of California's yearly workers' compensation budget. ${ }^{4}$

The allergic contact dermatitis of Toxicodendron plants is caused by the high allergenicity of the plant oleoresin urushiol, to which only man and several higher primates are sensitive. ${ }^{5}$ Peak frequency for sensitization occurs between 8 and 14 years of age. Infants are apparently not as easily sensitized as adults. ${ }^{6}$ Genetic susceptibility to urushiol sensitivity was suggested by the finding that $80 \%$ of children born to two urushiol-sensitive parents also became sensitive. ${ }^{7}$ Approximately $50 \%$ to $75 \%$ of the US adult population is clinically sensitive to poison ivy, oak, and sumac. In large urban areas, where these plants are less common, the prevalence is closer to $20 \%$. Ten percent to $15 \%$ of the population is tolerant. ${ }^{8,9}$

\section{Identification}

Poison ivy, poison oak, and poison sumac are all indigenous to the United States, Canada, and northern Mexico. Two species each of poison ivy and poison oak and 
Table 1. Characteristics of Toxicodendron plants

\begin{tabular}{|c|c|c|c|}
\hline Binomial name & Common name & Habitat & Identification aids \\
\hline $\begin{array}{l}\text { Toxicodendron } \\
\text { radicans }\end{array}$ & $\begin{array}{l}\text { Common or East- } \\
\text { ern poison ivy }\end{array}$ & $\begin{array}{l}\text { Eastern half of United } \\
\text { States and southern } \\
\text { Canada }\end{array}$ & $\begin{array}{l}\text { Groups of three ovate (widest below center) leaflets, each } \\
\text { 5- to } 15-\mathrm{cm} \text { long. Central leaflet usually bigger, with lon- } \\
\text { ger stem. Leaflet margins can be toothed, lobed, or flat. } \\
\text { Apex pointed. Stems usually with aerial rootlets. Grows } \\
\text { along roads, trails, and streams. Usually climbs as a } \\
\text { woody vine, but can be shrublike. }\end{array}$ \\
\hline $\begin{array}{l}\text { Toxicodendron } \\
\text { rydbergii }\end{array}$ & $\begin{array}{l}\text { Northern or West- } \\
\text { ern poison ivy }\end{array}$ & $\begin{array}{l}\text { Western half of United } \\
\text { States (except CA) and } \\
\text { northern border states }\end{array}$ & $\begin{array}{l}\text { Similar to } T \text { radicans. Thicker stems, less commonly with } \\
\text { aerial rootlets. Grows along roads, trails, and streams. } \\
\text { Small shrub } \sim 1 \mathrm{~m} \text { high. }\end{array}$ \\
\hline $\begin{array}{r}\text { Toxicodendron } \\
\text { diversilobum }\end{array}$ & $\begin{array}{l}\text { Western poison } \\
\text { oak }\end{array}$ & Pacific coast & $\begin{array}{l}\text { Groups of 3-5 oval leaflets, each } 3-7 \mathrm{~cm} \text { long. Leaflet } \\
\text { margins wavy to deeply lobed. Apex rounded. Stems } \\
\text { smooth, stiff, shrublike with aerial roots. In canyons and } \\
\text { riparian habitats, commonly grows as a climbing vine } \\
\text { with aerial rootlets that adhere to the trunks of oaks and } \\
\text { sycamores. Also forms dense thickets in chaparral and } \\
\text { coastal sage scrub. Regenerates quickly after disturbanc- } \\
\text { es, such as fire or clearing of land. }\end{array}$ \\
\hline $\begin{array}{l}\text { Toxicodendron } \\
\text { pubescens }\end{array}$ & Eastern poison oak & $\begin{array}{l}\text { Southeastern United } \\
\text { States }\end{array}$ & $\begin{array}{l}\text { Similar to } T \text { diversilobum. Variable leaf appearances that } \\
\text { can mimic white oak leaves. No aerial roots. Grows in } \\
\text { disturbed areas, especially common in sandy soils. Usu- } \\
\text { ally shrublike but can climb. }\end{array}$ \\
\hline $\begin{array}{l}\text { Toxicodendron } \\
\text { vernix }\end{array}$ & $\begin{array}{l}\text { Poison sumac or } \\
\text { dogwood }\end{array}$ & $\begin{array}{l}\text { Eastern third of United } \\
\text { States }\end{array}$ & $\begin{array}{l}\text { Groups of } 7-13 \text { leaflets, arranged as pairs along central rib, } \\
\text { with single leaflet at the end. Damp, swampy areas. Me- } \\
\text { dium-sized bush, grows } 6-20 \mathrm{ft} \text { high. }\end{array}$ \\
\hline
\end{tabular}

1 species of poison sumac are commonly found in the United States (Table 1). These plants are rarely found above 5000 feet elevation or in desert environments. ${ }^{10}$ The adage "leaves of three, let them be" refers to each leaf of poison ivy having 3 leaflets. Poison oak can have 3 to 5 leaflets, and sumac can have 7 to 13 leaflets. In

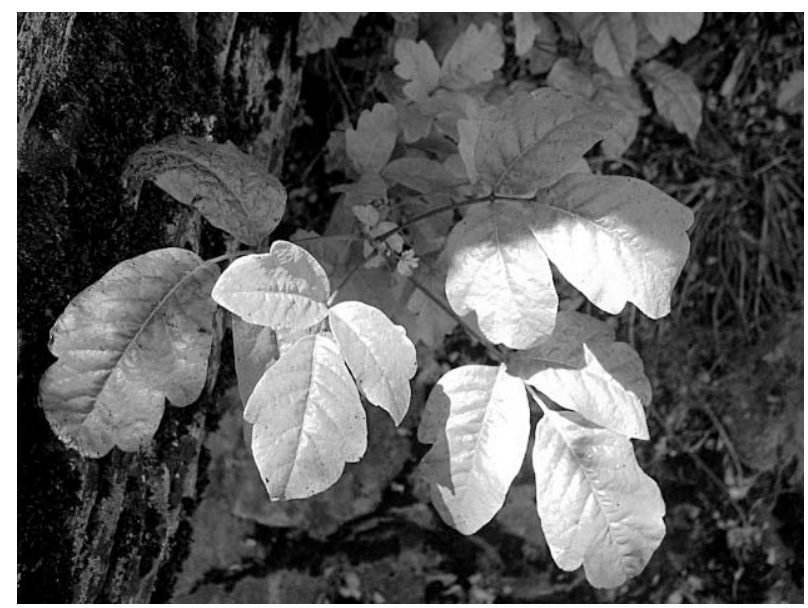

Figure 1. Poison oak (Toxicodendron diversilobum) in midsummer, found in a riparian zone along the Trinity River in Northern California. Photo by author. the eastern United States, poison ivy is often mistaken for another common native called Virginia creeper (Parthenocissus quinquefolia), which belongs to the Grape family and is nontoxic. Virginia creeper has a similar growth habit and seasonal color change, but typically has 5 leaflets instead of 3. An excellent resource for viewing and comparing images of these plants is the US Department of Agriculture's online PLANTS Database. ${ }^{11}$

Specific to all Toxicodendron species are clusters of green fruit that grow in the angle between the leaf and the twig from which it arises, and which take on an offwhite color when they mature in autumn. The leaf stalk also leaves a "U"- or "V"-shaped scar after it falls off.

Urushiol is colorless or slightly yellow in its natural state, but oxidizes, polymerizes, and turns black when exposed to air. The oil is found in the stems, roots, leaves, and skin of the fruits of these plants. It is nonvolatile and dries quickly on fomites, where it retains its antigenic potential in the dry state indefinitely (longevity is increased in dry climates and decreased in warm, moist climates). ${ }^{6}$ Usually, damage is required for plants to release the oil, therefore, slight contact with uninjured leaves is innocuous. More vigorous activities, such as weeding or cleaning brush, or cross-country travel and 
Table 2. Characteristics of plants containing uroshiol cross-reacting chemicals

\begin{tabular}{|c|c|c|}
\hline Binomial name (family) & Common name & Notes \\
\hline $\begin{array}{l}\text { Toxicodendron verniciflua } \\
\quad \text { (Anacardiaceae) }\end{array}$ & Japanese lacquer tree & $\begin{array}{l}\text { Found in Japan and China. The viscous, self-melanizing } \\
\text { sap has been used for varnishing wood for centuries. }\end{array}$ \\
\hline $\begin{array}{l}\text { Semecarpus anacardium } \\
\quad \text { (Anacardiaceae) }\end{array}$ & Indian marking nut tree & $\begin{array}{l}\text { Found in Southeast Asia, Pacific Islands, and Australia. } \\
\text { The black juice is mixed with alum to mark laundry. } \\
\text { Indian dhobis (laundry workers) can develop dermatitis, } \\
\text { and wearers of marked garments can be exposed. }\end{array}$ \\
\hline $\begin{array}{l}\text { Mangifera indica (Anacar- } \\
\text { diaceae) }\end{array}$ & Mango tree & $\begin{array}{l}\text { Found in the tropics. Urushiol and cardol, a resorcinol, is } \\
\text { found in the leaves, stems, skin, and sap. Recent re- } \\
\text { search has shown a cross-sensitivity to mango in uru- } \\
\text { shiol-sensitized individuals. }{ }^{19}\end{array}$ \\
\hline $\begin{array}{l}\text { Anacardium occidentale } \\
\quad \text { (Anacardiaceae) }\end{array}$ & Cashew nut tree & $\begin{array}{l}\text { Found in the tropical Americas. High concentrations of } \\
\text { cross-reacting resorcinols are found within the oil be- } \\
\text { tween nutshell layers. Proper roasting is required to de- } \\
\text { activate these compounds. }\end{array}$ \\
\hline $\begin{array}{l}\text { Schinus terebinthifolius } \\
\quad \text { (Anacardiaceae) }\end{array}$ & $\begin{array}{l}\text { Brazilian pepper tree or } \\
\text { Florida holly }\end{array}$ & $\begin{array}{l}\text { Native to South America, but now endemic in Florida and } \\
\text { Hawaii. The sap and crushed berries cause the majority } \\
\text { of allergic contact dermatitis cases in southern Florida. }\end{array}$ \\
\hline $\begin{array}{l}\text { Ginkgo biloba (Ginkgo- } \\
\text { aceae) }\end{array}$ & Ginkgo tree & $\begin{array}{l}\text { Widely cultivated in North America and Europe. The sen- } \\
\text { sitizing ginkgolic acid is found within the soft outer } \\
\text { layer of the seed. }\end{array}$ \\
\hline
\end{tabular}

bushwhacking, can transfer the oil onto the skin. As little as $2 \mathrm{mg}$ can cause a reaction in sensitive individuals.

In the fall, the leaves turn red and become enriched with urushiol. In winter, as the leaves become dry and fall off, urushiol and other essential nutrients are resorbed into the plant, making the fallen leaves nonallergenic. ${ }^{12}$ Indeed, nonleaf parts of the plant are often the only visible portion in winter, and unintentional contact resulting from failure to identify the plant can cause severe dermatitis.

\section{Immunochemistry}

The allergic contact dermatitis induced by urushiol, a phenolic lipid, has been studied for several decades. ${ }^{13-}$ ${ }^{15}$ Much has been learned regarding the molecular structure and immunology of the compound, including the synthesis of the allergenic catechol side chains. ${ }^{16-18}$ Urushiol is a mixture of 3-n-pentadecylcatechols, which contain a catechol ring moiety substituted with different aliphatic side chains at position 3 or 4 . Poison ivy generally has a C-15 carbon side chain that can be completely saturated or have 1, 2, or 3 unsaturated bonds. Poison oak has a C-17 side chain that is rarely saturated, and poison sumac has a $\mathrm{C}-13$ side chain. Both the catecholic ring and the aliphatic chain play important roles in the allergenicity of urushiol. ${ }^{16}$ Specifically, the pres- ence of a side chain at position 3 confers increased antigenicity, as does unsaturation at the same site.

The urushiols in poison ivy, poison oak, and poison sumac differ only slightly in structure and they crossreact, thus, a person sensitized to one will react to all. Similar compounds found in other members of the Anacardiaceae family, as well as in several non-Anacardiaceae plants, can lead to cross-reactions and to an identical clinical picture (Table 2). However, dermatitis induced by these cross-reactors is rare compared with the frequency of dermatitis from Toxicodendron species. The allergens in the non-Toxicodendron plants listed in Table 2 are generally noncatechol phenols and resorcinols, and not the highly allergenic catechols in poison ivy, oak, and sumac. The hypothesis that early skin exposure to catechols may allow cross-reaction to other Anacardiaceae, whereas early oral exposure to phenols and resorcinols may induce tolerance, has been expressed. ${ }^{20,21}$

\section{Pathophysiology}

The typical allergic contact dermatitis is initiated by a $\mathrm{T}$ lymphocyte-mediated delayed type hypersensitivity reaction to urushiol. ${ }^{22}$ After initial contact, urushiol catechols avidly bind to and penetrate the skin, where they are oxidized to quinone intermediates and bind surface proteins on antigen-presenting cells in the epidermis 


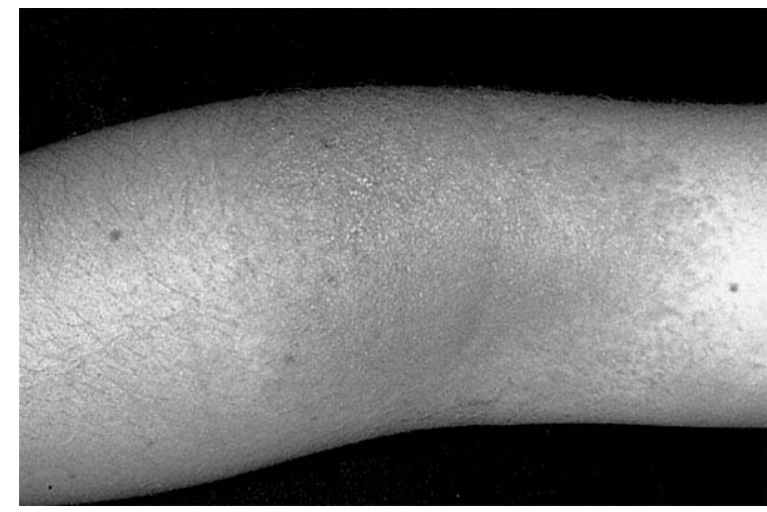

Figure 2. Early Toxicodendron dermatitis. Erythema and tiny papular lesions in a typically exposed area. Photo by Thomas P. Habif, MD, from www.dermnet.com.

(Langerhan's cells) and dermis (macrophages). The antigen-presenting cells internalize and process the antigen, migrate to regional lymph nodes, and present processed antigen to CD4 T-helper lymphocytes. The activated T cell forms a clone of urushiol-specific T-effector and Tmemory lymphocytes.

After subsequent contact, these clonal lymphocytes elicit a cell-mediated cytotoxic immune response characterized by vesiculation, edema, and erythema through destruction of epidermal cells and activation of dermal vasculature.

Keratinocytes also contribute to the allergic reaction. ${ }^{23,24}$ Functioning in an antigen-independent fashion, these cells produce a variety of cytokines, including an early response with interferon- $\gamma$ and tumor necrosis factor $\alpha$ and a later response with interleukins-1, -6 , and -8 , and granulocyte-macrophage colony stimulating factor-all primarily amplifying inflammatory responses. ${ }^{22,25,26}$ Monocyte production of prostaglandins, leu-

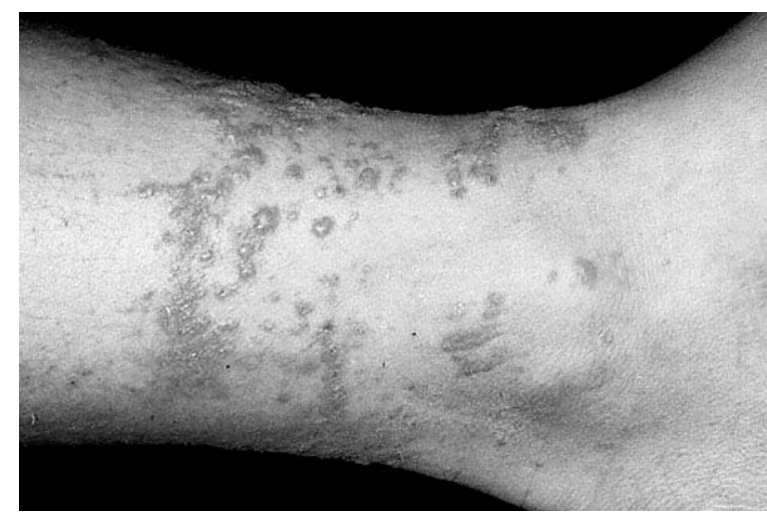

Figure 3. Progressing Toxicodendron dermatitis. Large streaks of erythema and vesicles in a typically exposed area. Photo by Thomas P. Habif, MD, from www.dermnet.com.

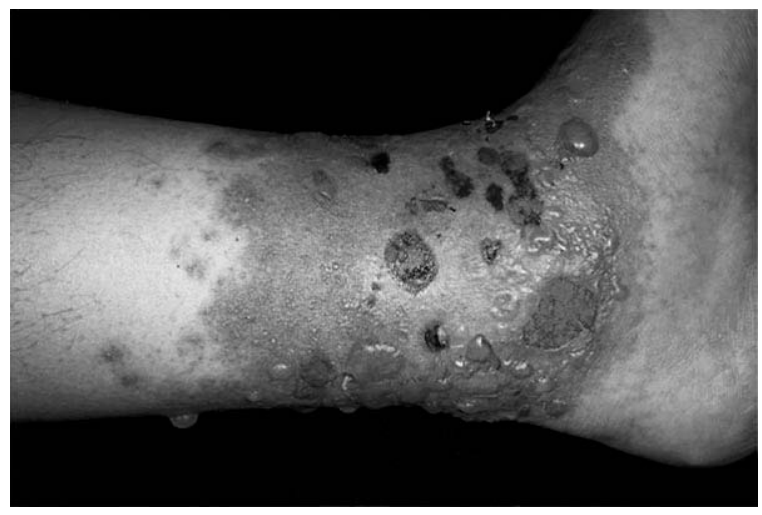

Figure 4. Late Toxicodendron dermatitis. A severe case showing erythema, vesicles, and fluid-filled bullae in different stages of healing. Photo by Thomas P. Habif, MD, from www.dermnet.com.

kotrienes, and other metabolites are the major contributors to the delayed inflammatory response, and are the targets of corticosteroid treatment.

\section{Clinical features}

A sensitized person typically develops an erythematous, intensely pruritic eruption within 2 days of exposure. The delay between exposure and eruption is most often 24 to 48 hours, with a range of 5 hours to 15 days. ${ }^{27}$ Streaks or areas of erythema and edematous papules (Figure 2) precede vesicles and bullae (Figures 3 and 4). When seen within hours to days after a likely exposure, the development of lesions in a linear array substantially aids diagnosis (Figure 5). The mildest reactions usually lack vesicles, whereas severe reactions can produce confluent bullae, severe edema, and extreme discomfort. Urushiol can be aerosolized in smoke, and, in wildland

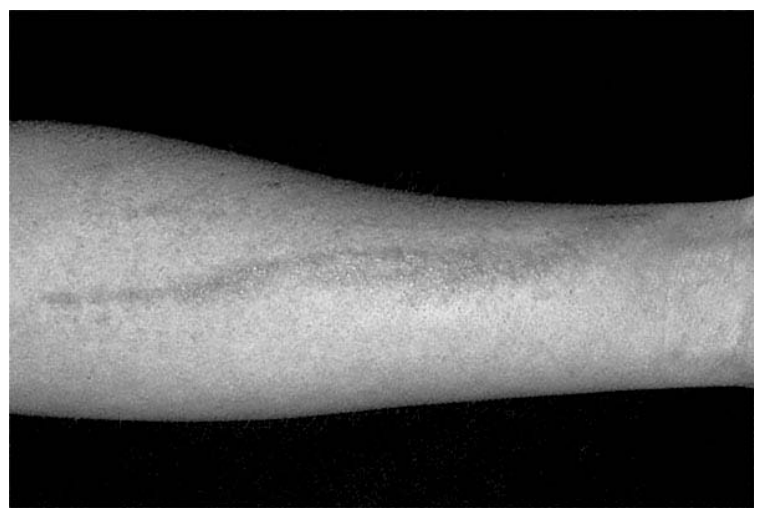

Figure 5. Linear rash in early Toxicodendron dermatitis. Classic presentation of a distinct linear rash of erythema and papules within 2 to 3 days of a known exposure. Photo by Thomas P. Habif, MD, from www.dermnet.com. 
firefighters, has caused respiratory tract inflammation and generalized dermatitis.

Without treatment, the typical dermatitis resolves in approximately 3 weeks, but can last up to 6 weeks in very susceptible individuals. Individual variations in the time course of Toxicodendron dermatitis have been studied by several investigators, but no consensus on particular risk factors has been reached. ${ }^{27-29}$ Black-spot dermatitis is a rare manifestation of the common condition. The initial presentation is asymptomatic black lesions on the skin that cannot be washed off, with the typical skin eruption occurring superimposed later. These lesions have been mistaken for melanoma in several cases. ${ }^{30}$ If the sap is deposited in sufficient amounts, these black deposits permanently stain clothing and cannot be removed by washing. Indeed, the sap of the Toxicodendron relative, Semecarpus anacardium, is used to mark laundry in India and causes dermatitis in both laundry dhobis and garment wearers.

Erythema multiforme has also been described as a complication of poison ivy exposure. ${ }^{31}$ In the reported cases, patients with severe dermatitis developed the classic widespread pruritic papules and target lesions on the torso, extremities, palms, and soles within 4 to 14 days of the dermatitis onset. None had previous herpes simplex virus exposure. The authors suggest that erythema multiforme may be an underreported nonspecific reaction pattern to severe Toxicodendron contact dermatitis.

Contrary to popular belief, vesicular fluid contains no antigen and is not responsible for spreading the rash. Variations in the time of appearance of clinical reactions at different sites are caused by differences in antigen load and in epidermal thickness. Contact with latent oil is the reason new lesions develop 2 to 3 weeks after the first symptoms. The most common reservoirs for reexposure are fingernails, clothing, tools and equipment, and pets. ${ }^{32}$ An exception is transfer from the thick skin of the hands and fingers to the genitalia immediately after initial exposure. In this setting, lesions may not even develop on the hands but do develop on the genitalia, with its thin stratum corneum.

Differential diagnosis should include chemical irritant dermatitis, bedbug (Cimex lectularius) bites, phytophotodermatitis, and nummular eczema. ${ }^{5,33}$ Irritant dermatitis and bedbug bites produce immediate reactions, unlike the delayed onset of poison ivy/oak/sumac dermatitis, and often appear as linear lesions but usually lack a vesicular or bullous reaction. Phytophotodermatitis is usually nonpruritic and occurs in sun-exposed areas only, usually 12 to 24 hours after sensitizing plants (celery, parsley, limes, figs) have contacted an area of skin that is subsequently exposed to ultraviolet radiation. The dermatitis of poison ivy/oak/sumac affects both covered and exposed areas, most commonly on the arms, legs, and face. Individuals with nummular eczema often have a history of atopy and repeated eruptions not corresponding to Toxicodendron exposure.

Complications are uncommon in most individuals, and are usually limited to transient postinflammatory hyperpigmentation and secondary infection. Hyperpigmentation occurs more commonly in black skin than in lighter skin, and may persist for months. ${ }^{5}$ A retrospective study of 33 patients with secondarily infected poison ivy dermatitis showed polymicrobial infections in half of the patients, with Staphylococcus aureus, Group A $\beta$-hemolytic strep, Prevotella, Porphyromonas, and Fusobacterium being the most common isolates. ${ }^{34}$ An extremely rare and serious complication of Toxicodendron dermatitis is the development of nephrotic syndrome, with deposition of immunoglobulin-immune complexes in kidney nephrons. ${ }^{35}$

\section{Treatment}

Urushiol is easily degraded in water. However, the oil can be removed in clinically significant amounts only if washed off immediately. ${ }^{36}$ At 10 minutes, $50 \%$ can be removed; at 15 minutes, $25 \%$; at 30 minutes, only $10 \%$; and after 30 minutes, all of the oil has been absorbed. A gentle, cold-water rinse with mild soap should be used as early as possible. Overly enthusiastic scrubbing may increase the area of exposure. Some investigators have suggested using just water and avoiding soap (presumably to prevent initial spread of emulsified oil). If washing is not possible within 30 minutes, it may still be worthwhile to wash at the first opportunity to avoid any continued exposure from contaminated clothing. All exposed clothing, equipment, and pets should be washed thoroughly in soap and water.

Three over-the-counter products are commercially available for postexposure treatment. Tecnu (Tec Laboratories, Albany, OR), an organic solvent marketed in forestry magazines as a waterless detoxification system, provided total protection (no clinical symptoms) in $70 \%$ of sensitized individuals when applied within 2 hours after exposure. ${ }^{37}$ This small $(n=20)$, nonrandomized study compared skin reactions in proven responders when Tecnu and 2 other commercially available soaps were applied after a laboratory exposure to urushiol. Although after-test comparisons showed no significant differences between agents $(P>.05)$, there was a significant improvement in reducing dermatitis over controls $(P<.007)$. The authors suggest that Tecnu-a crude distillate of gasoline that was originally developed to remove radioactive fallout dust from the skin without water ${ }^{38}$ - should provide significant relief of Toxicoden- 
dron dermatitis if applied within 2 hours of exposure. They also conclude, however, that the products, Goop and Dial Ultra dishwashing soap, can provide protection that is not significantly different from the more-expensive Tecnu. Another commercially available product, Zanfel (Zanfel Laboratories Inc, Morton, IL), is a soap mixture of the fatty acid, ethoxylate, and the surfactant, lauroyl sarcosinate. A randomized, double-blind, placebo-controlled study reports an improvement in erythema, induration, and vesiculation at 48, 96, and 144 hours, with use after laboratory exposure, as compared with placebo. ${ }^{39}$ This small $(n=24)$ study showed significant $(P<.05)$ reductions in objective dermatitis scores in subjects who washed with the solvent compared to placebo after being experimentally exposed to urushiol antigen. These studies are obviously underpowered, and are also limited by differing applications and concentrations of experimental urushiol, differing dermatitis severity scores and possible reporting bias, and unclear baseline determination and randomization of urushiol sensitivities. Dr. West's Ivy Detox Cleanser, a chelator that presumably deactivates urushiol in the dermis, has not been formally studied. Clearly, more research is required before specific recommendations for any product can be made, although all seem safe for over-the-counter use as long as the manufacturer's directions are followed.

Symptomatic relief of the pruritis associated with acute poison ivy/oak/sumac dermatitis includes tepid baths with baking soda or colloidal oatmeal, cool compresses, and calamine lotion. Oral antihistamines can also be given for pruritis. A Burow's astringent solution (aluminum acetate, available over the counter as Domeboro powder packets, mixed in tap water 1:40) can be applied as a wet-to-dry dressing to cool and dry weeping lesions. Topical antihistamines and antibiotics can be sensitizing and exacerbate existing lesions, and should be avoided. ${ }^{40}$ The plant jewelweed (Impatiens biflora), first used by Native Americans in the Appalachian area, is reputed to be effective in treating poison ivy dermatitis, and has been extracted and included in several over-the-counter preparations. However, a randomized, double-blind study found that jewelweed is not effective in the treatment of poison ivy/oak allergic contact dermatitis. ${ }^{41}$

Topical steroids are readily absorbed and can cause thinning of the skin and adrenal suppression with continued use. The amount required to treat advanced, severe, or widespread dermatitis limits their usefulness, although application is justified in early reactions when erythema and pruritis are present but no vesicles have appeared. In such situations, moderate-strength creams, such as $0.1 \%$ triamcinolone or $0.1 \%$ betamethasone ap- plied 2 to 3 times daily may avert spread of the rash. Abrupt discontinuation can cause a rebound inflammatory response. Moderate-strength steroid creams should never be used on the face or genitalia. Less-potent agents ( $1 \%$ hydrocortisone or $0.2 \%$ hydrocortisone valerate) can be used in these areas and for children. ${ }^{25}$

Tacrolimus and pimecrolimus, two topical immunosuppressive treatments that work by inhibiting calcineurin and, thus, T-cell activation in the skin, have been studied as safer alternatives to topical steroids for atopic dermatitis. A meta-analysis of randomized controlled trials shows that topical $0.1 \%$ tacrolimus is as effective as potent topical steroids and more effective than mild topical corticosteroids for treating inflammatory skin disorders and atopic dermatitis. ${ }^{42}$ The authors found no clear evidence, however, that this more-expensive treatment offers protection from thinning of skin or adrenal suppression. Another randomized placebo-controlled trial has shown that $1 \%$ pimecrolimus cream is ineffective specifically in the treatment of Toxicodendron allergic contact dermatitis. ${ }^{43}$

Systemic corticosteroids, whether intramuscular, intravenous, or oral, are the mainstay of treatment in moderate-to-severe poison ivy/oak/sumac dermatitis, and can offer immediate and significant relief if administered early. Doses are typically 1 to $2 \mathrm{mg}$ per $\mathrm{kg}$ per day $(0.5$ $\mathrm{mg}$ per $\mathrm{kg}$ per day in children), administered in a single morning dose during a 7- to 10-day period, followed by a taper of another 7 to 10 days. Steroid-resistant rebound flares can occur if the dose is too low or the course is too short. ${ }^{44,45}$ When compliance may be an issue, $40 \mathrm{mg}$ triamcinolone acetonide suspension can be given intramuscularly. One injection is usually effective for the required treatment period, but patients should be warned of possible rebound. ${ }^{9}$ In cases in which systemic steroids are contraindicated, some investigators suggest use of moderately potent topical corticosteroids with 24-hour occlusion. ${ }^{46}$ The method recommended consists of moderate-strength topical steroids under occlusion for 224 hour periods, with a day of no treatment in between.

\section{Prevention}

Proper identification and avoidance of Toxicodendron species is the best prevention. Strict avoidance of these plants is impractical, however, for people with occupations or recreation interests that take them outdoors in endemic areas. Fabric can be an effective barrier, but can also harbor urushiol indefinitely and must be carefully removed and laundered without skin contact. Most Toxicodendron rashes tend to occur through sweaty, thin clothing, such as occurs during exertion while wearing a T-shirt. When moisture is present, the antigen seems 
to "wick" through the cloth and deposit on the skin before being broken down. Dry, loosely woven fabrics are most protective because they mechanically keep the broken stems and leaves away from the skin. Urushiol penetrates latex but not vinyl gloves. ${ }^{36}$

Desensitization programs for sensitized individuals have not been successful. ${ }^{36,47}$ Systematic oral ingestion of leaves or injection of prepared extracts usually results in pruritis ani, generalized pruritis, and urticaria. Hyposensitization effects seem to wane in 6 to 12 months. Lasting natural hyposensitization has been reported, however, among Japanese woodworkers who use lacquer derived from Toxicodendron verniciflua, the Japanese lacquer tree. In a 1991 survey, $81 \%$ of craftsmen developed dermatitis from the lacquer but $83 \%$ of these reactions resolved with continued exposure. ${ }^{48,49}$ According to traditional Asian medicine, ingestion of this lacquer is a remedy for gastrointestinal disorders. In Korean folk medicine, the leaves, roots, and bark of this tree are boiled and the extract is ingested, apparently without systemic symptoms. 50

Many barrier creams have been developed and tested. A randomized, double-blind study of seven different commercially available barrier creams found 3 products that offered a statistically significant reduction in dermatitis severity. ${ }^{51}$ This small $(n=20)$, well-controlled, rigorously analyzed study showed a percentage decrease in global dermatitis severity for the 7 products as follows: Stokogard (Stockhausen, Greensboro, NC), 59\%; Hollister Moisture Barrier (Hollister Incorporated, Libertyville, CA), 52\%; Hydropel (Genesis Pharmaceuticals, Inc, Hazel Park, MI), 48\%; Ivy Shield (Interpro, Haverhill, MA), 22\%; Shield Skin (Mentor Corporation, Santa Barbara, CA), 13\%; Dermofilm (Innovatec, NSW, Australia), 13\%; and Uniderm (Uniderm Hellas K. Zoras, Glyka Nera, Greece), 9\%. Stokogard and Ivy Shield are marketed specifically for prevention of Toxicodendron dermatitis, and the others for prevention of irritant dermatitis in general. A significantly higher number of test sites treated with the best-performing preparations were also completely free of dermatitis, whereas one product (Uniderm) actually appeared to enhance the rash. The authors concluded that Stokogard, Hollister Moisture Barrier, and Hydropel are effective in the prevention of Toxicodendron dermatitis. Another randomized, single-blind study examined prevention of Toxicodendron dermatitis by the organoclay compound, $5 \%$ quaternium-18 bentonite lotion (Ivy-Block, Enviroderm Pharmaceuticals, Louisville, KY). ${ }^{52}$ In 144 proven urushiol responders, lotion application completely prevented dermatitis in $68 \%$ and reduced symptoms in the remaining $32 \%$ when compared with controls. This product has been approved by the Food and Drug Admin- istration for prevention of Toxicodendron dermatitis. Topical Skin Protectant, a barrier cream containing polytetrafluoroethylene resin mixed in a perfluorinated polyether oil (chemicals related to Teflon), has been tested by the military for prevention, but is not yet commercially available. ${ }^{53}$ Ongoing interest in a Toxicodendron "vaccine" persists; a recent study found some efficacy in down regulation of the allergic contact dermititis response in sensitized rats after treatment with a monoclonal antibody to the urushiol antigen. ${ }^{54}$

\section{Summary}

The Toxicodendrons plants - poison ivy, poison oak, and poison sumac — are found throughout the United States, southern Canada, and northern Mexico, and are commonly encountered by outdoor workers and travelers. The allergic contact dermatitis from these plants most commonly presents with a linear, erythematous, papulovesicular rash and associated pruritis and weeping. Recognition and avoidance are the most important preventative measures. Prophylactic barrier creams should be considered in severely sensitive individuals or those with occupational exposure. Immediate use of water and mild soap, or of a commercially available postexposure solvent within a few hours, can decrease or prevent clinical symptoms. Antihistamines and topical therapy with bland shake lotions help to control symptoms. Topical steroids and antibiotics should generally be avoided. One to $2 \mathrm{mg}$ per $\mathrm{kg}$ per day of systemic corticosteroids for 14 to 21 days can provide significant relief in more severe cases. Inadequate doses or courses of steroids can cause rebound dermatitis, but persistent or recurrent cases should prompt investigation of repeated exposure from contaminated clothing or equipment.

\section{Acknowledgments}

The author thanks Peter J. Lynch, MD, Chair of the University California at Davis Department of Dermatology, for his support of this project. The author has no financial relationships with commercial entities that may pose a conflict of interest.

\section{References}

1. Pariser DM, Ceilley RI, Lefkovits AM, Katz BE, Paller AS. Poison ivy, oak and sumac. Derm. Insights. 2003;4(1): 26-28.

2. Schappert SM. Ambulatory care visits to physician offices, hospital outpatient departments, and emergency departments: United States, 1996. National Center for Health Statistics. Vital Health Stat. 1998;13(134):26. 
3. Oltman J, Hensler R. Poison oak/ivy and forestry workers. Clin Dermatol. 1986;4(2):213-216.

4. Epstein WL. Occupational poison ivy and oak dermatitis. Dermatol Clin. 1994;12:511-516.

5. Fisher AA. Poison ivy/oak/sumac. Part II: specific features. Cutis. 1996;58:22-24.

6. Fisher AA, Mitchell JC. Toxicodendron plants and spices. In: Rietschel RL, ed. Fisher's Contact Dermatitis. 4th ed. Baltimore, MD: Williams \& Wilkins; 1995:461-523.

7. Epstein WL. The poison ivy picker of Pennypack Park: the continuing saga of poison ivy. J Invest Dermatol. 1987;88(suppl 3):7-11.

8. Marks JG. Poison ivy and poison oak allergic contact dermatitis. J Allergy Clin Immunol. 1989;9:497-506.

9. Baer RL. Poison ivy dermatitis. Cutis. 1990;46:34-36.

10. Epstein WL, Epstein JH. Plant-induced dermatitis. In: Auerbach PS, ed. Wilderness Medicine. 3rd ed. St. Louis, MO: Mosby-Year Book; 1995:843-861.

11. Natural Resources Conservation Service, United States Department of Agriculture. PLANTS Database. Available at: http://plants.usda.gov/index.html. Accessed on 11/15/ 05; search term: Toxicodendron.

12. Gartner BL, Wasser C, Rodriguez E, Epstein WL. Seasonal variation of urushiol content in poison oak. Am J Contact Dermatitis. 1993;4:33-36.

13. Symes WF, Dawson CR. Poison ivy urushiol. J Am Chem Soc. 1954;76:2959-2963.

14. Baer H. Chemistry and immunochemistry of poisonous Anacardiaceae. Clin Dermatol. 1986;4:152-159.

15. Guin JD, Beaman JH. Toxicodendrons of the United States. Clin Dermatol. 1986;4:137-148.

16. Dawson CR. The chemistry of poison ivy. Trans $N$ Y Acad Sci. 1956;18:427-443.

17. Symes WF, Dawson CR. Separation and structural determination of the olefinic components of poison ivy urushiol, cardonal and cardol. Nature. 1953;171:841-842.

18. Du Y, Oshima R, Kumanotai J. Reversed-phase liquid chromatographic separation and identification of constituents of urushiol in the sap of the lac tree. J Chromatogr. 1985; A284:463-473.

19. Oka K, Fumio S, Tadashi Y, Akiko S. A study of crossreactions between mango contact allergens and urushiol. Contact Dermatitis. 2004;51:292-296.

20. Knight TE, Boll P, Epstein WL, Prasad AK. Resorcinols and catechols. A clinical study of cross-reactivity. Am J Contact Dermatol. 1996;7:138-145.

21. Klilah H, Ido W, Arieh I. Exploring the mango-poison ivy connection: the riddle of discriminative plant dermatitis. Contact Dermatitis. 2005;52:3-5.

22. Kalish RS. Recent developments in the pathogenesis of allergic contact dermatitis. Arch Dermatol. 1991;127: 1558-1563.

23. Barker JN. Role of epidermal keratinocytes in allergic contact dermatitis. Contact Dermatitis. 1992;26(3):145-148.

24. Kupper TS. Production of cytokines by epithelial tissues. A new model for cutaneous inflammation. Am J Dermatopathol. 1989;11(1):69-73.
25. Mydlarski PR, Katz AM, Mamelak, AJ, Sauder DN. Contact dermatitis. In: Adkinson NF, ed. Middleton's Allergy: Principles and Practice. 6th ed. St. Louis, MO: Mosby; 2003:1581-1593.

26. Wakabayashi T, Hu DL, Tagawa YI, et al. IFN $\gamma$ and TNF are involved in urushiol-induced contact hypersensitivity in mice. Immunology Cell Bio. 2005;83:18-24.

27. Williams JV, Light J, Marks JG. Individual variations in allergic contact dermatitis from urushiol. Arch Dermatol. 1999;135:1002-1003.

28. Guin JD. Reaction time in experimental poison ivy dermatitis. Contact Dermatitis. 1980;6:289.

29. Lejman E, Stoudemayer T, Grove G, Kligman AM. Age differences in poison ivy dermatitis. Contact Dermatitis. 1984;11:163-167.

30. Kurlan JG, Lucky AW. Black spot poison ivy: a report of 5 cases and a review of the literature. $J$ Am Acad Dermatol. 2001;45:246-249.

31. Werchniak AE, Schwarzenberger K. Poison ivy: an underreported cause of erythema multiforme. J Am Acad Dermatol. 2004;51:159-160.

32. Tanner TL. Rhus (Toxicodendron) dermatitis. Primary Care. 2000;27(2):493-502.

33. Juckett G. Plant dermatitis - possible culprits go far beyond poison ivy. Postgrad Med. 1996;100(3):159-163.

34. Brook I, Frazier EH, Yeager JK. Microbiology of infected poison ivy dermatitis. Brit J Dermatol. 2000;142:943-946.

35. Devich KB, Lee JC, Epstein WL, Spitler LE, Hopper JJ. Renal lesions accompanying poison oak dermatitis. Clin Nephrol. 1975;3(3):106-113.

36. Fisher AA. Poison ivy/oak dermatitis. Part 1: preventionsoap and water, topical barriers, hyposensitization. Cutis. 1996;57:384-386.

37. Stibich AS, Yagan M, Sharma V, Herndon B, Montgomery C. Cost-effective post-exposure prevention of poison ivy dermatitis. Int J Dermatol. 2000;39:515-518.

38. Armstrong WP, Epstein WL. Poison oak: more than just scratching the surface. Herbalgram. 1995;34:36.

39. Davila A, Lucas J, Laurora M, Jacoby J, Reed J, Heller M. A new topical agent, Zanfel, ameliorates urushiol-induced Toxicodendron allergic contact dermatitis [abstract 364]. Annals Emerg Med. 2003;42(suppl 4):s98.

40. Williford PM, Sherertz EF. Poison ivy dermatitis-nuances in treatment. Arch Fam Med. 1994;3:184-188.

41. Long D, Ballentine NH, Marks JG. Treatment of oison ivy/ oak allergic contact dermatitis with an extract of jewelweed. Am J Contact Dermatitis. 1997;8(3):150-153.

42. Ashcroft DM, Dimmock P, Garside R, Stein K, Williams HC. Efficacy and tolerability of topical pimecrolimus and tocrolimus in the treatment of atopic dermatitis: meta-analysis of randomized controlled trials. BMJ. 2005;330:516525 .

43. Amrol D, Keitel D, Hagaman D, Murray J. Topical pimecrolimus in the treatment of human allergic contact dermatitis. Ann Allergy Asthma Immunol. 2003;91(6):563566. 
44. Wooldridge WE. Acute allergic contact dermatitis: how to manage severe cases. Postgrad Med. 1990;87:221-224.

45. Ives TJ. Failure of a tapering dose of oral methylprednisolone to treat reactions to poison ivy. JAMA. 1991;266: 1367.

46. Guin JD. Treatment of Toxicodendron dermatitis. Skin Therapy Lett. 2001;6(7):3-5.

47. Marks JG, Trautlein JJ, Epstein WL, Laws DM, Sicard GR. Oral hyposensitization to poison ivy and poison oak. Arch Dermatol. 1987;23(4):476-478.

48. Kawai K, Mikio N, Kyozo K, et al. Hyposensitization to urushiol among Japanese lacquer craftsmen. Contact Dermatol. 1991;25:290-295.

49. McGovern TW. Dermatoses due to plants. In: Bolognia JL, ed. Dermatology. St. Louis, MO: Mosby; 2003:265283.

50. Oh SH, Haw CR, Lee MH. Clinical and immunologic features of systemic contact dermatitis from ingestion of
Rhus (Toxicodendron). Contact Dermatitis. 2003;48:251254.

51. Grevelink SA. Effectiveness of various barrier preparations in preventing and/or ameliorating experimentally produced Toxicodendron dermatitis. J Am Acad Dermatol. 1992;27:182-188.

52. Marks JG, Fowler JF, Sherertz EF, Rietschel RL. Prevention of poison ivy and poison oak allergic contact dermatitis by quaternium-18 bentonite. J Am Acad Dermatol. 1995;33:212-216.

53. Vidmar DA, Iwane MK. Assessment of the ability of the topical skin protectant (TSP) to protect against contact dermatitis to urushiol antigen. Am J Contact Dermatitis. 1999;10(4):190-197.

54. Baldwin RW, Clegg JA, Curran AC. Regulation of the contact sensitivity response to urushiol with anti-urushiol monoclonal antibody ALG 991. Arch Dermatol Res. 1999; 291:652-658. 